\title{
Entrepreneurs responding to the COVID-19 crisis: evidence from Ireland
}

Research Article

\author{
Simon Stephens ${ }^{1 *}$, Christopher McLaughlin², Katrina McLaughlin ${ }^{3}$ \\ 1 Faculty of Business, Letterkenny Institute of Technology, Port Road, Letterkenny, Donegal, F92 FC93, Ireland \\ 2 Department of Global Business and Enterprise; Department, University of Ulster, Magee Campus Londonderry BT48 7JL, UK \\ 3 School of Psychology, Queens University Belfast, University Rd, Belfast BT7 1NN, United Kingdom, UK
}

\begin{abstract}
The aim of this paper is to explore the impact that the initial stages of the COVID-19 crisis had on entrepreneurs. We present the experiences of fifteen entrepreneurs. The data was collected, using interviews. We focus on the impact that the temporary business closures which were introduced had on the entrepreneurs' ability and propensity to continue. The interviews took place during a period of great uncertainty for the entrepreneurs and at times when their availability was extremely limited. We present data characterising the entrepreneurs; their experience during a time of crisis; and the enablers and disablers to the continuation of their entrepreneurial journey. Our analysis is based on four themes from the literature: the psychological wellbeing of the entrepreneurs; their changing attitudes to entrepreneurship; the changes they made to their business; and the supports that they needed. The outcome is novel insights into the impacts of the COVID-19 crisis.
\end{abstract}

Keywords: Psychological wellbeing, crisis, entrepreneurial journey, resilience, COVID-19

(c) Sciendo

\section{INTRODUCTION}

The World Health Organisation (WHO) declared COVID-19 a pandemic on March 11th, 2020 (Liguori and Winkler 2020). As a result, social activity changed and there was a significant decrease in economic activity (Ratten 2020). Authors including (Alonso et al., 2020; Cowling et al., 2020; Foss, 2020; and Liguori and Pittz, 2020) reflect that all crises, whatever their origin, have an immediate and severe impact on entrepreneurs. Therefore, the aim of this paper is to capture the experiences of entrepreneurs who endured closures and operational restrictions. We do this to understand the challenges they face in continuing their entrepreneurial journey.

Although the COVID-19 crisis is a relatively recent occurrence, there is an emergent literature on the topic (Alonso et al., 2020; Bartik, et al., 2020; Cowling, et al., 2020; Kuckertz et al., 2020; Liguori and Pittz, 2020; Nummela et al., 2020; Papadopoulos, 2020; Ratten, 2020; Stephens et al., 2021b; Zinghan et al., 2021). In this paper we add to this literature by presenting evidence from Ireland. Given the economic importance of small businesses to the Irish economy, additional research is needed to understand how their owners think and act in relation to the COVID-19 crisis. The overall aim is to understand the entrepreneurs' motivations, experiences and reflections on the process of (re)starting the entrepreneurial journey after a crisis episode. The findings from this study provide novel insights with regard to the resources and strategies used by entrepreneurs during a time of crisis.

Ratten (2020) explains that when studying the initial impacts of COVID-19 researchers need to be inventive with the design of their data collection process, which may need to take place at speed. Nummela et al. (2020) propose that researchers should adopt a narrative based approach when exploring how COVID-19 has changed the lives of entrepreneurs. In this paper we present the story of entrepreneurship from the perspective of fifteen entrepreneurs who experienced a range of challenges and adopted a range of strategies during the first six months 
(April - September 2000) of the COVID-19 restrictions on business activity. We begin by examining the issues associated with crisis episodes in entrepreneurship, as it relates to the emergent literature on COVID-19. Then we present evidence from the interviews with the fifteen entrepreneurs and finally, we present our conclusions, recommendations and future research directions.

\section{ENTREPRENEURS AND CRISIS EPISODES}

The business community, specifically, entrepreneurs, have during 2020-2021 operated in a volatile business environment. They will again face significant uncertainty in 2022. Spillan and Hough (2003) warn that not only can a crisis adversely impact business owners and entrepreneurs, it can destroy the business entity and wreak havoc on suppliers, customers, partners, competitors, families and the community in which the business is based. The literature on crisis episodes and entrepreneurial activity is limited, but notable articles include: Spillan and Hough (2003), Papaoikonomou et al. (2012), Doern et al., (2019); and Brown et al. (2020). Giones et al. (2020) explain that although the COVID-19 crisis impacts all types of economic activity, public support programs tend to prioritize and protect established and/or larger organizations. Furthermore, Brown et al. (2020) report that the attention of policy makers and support agencies has centered on the immediate impacts that the COVID-19 crisis has had for existing businesses, in terms of their ability to maintain staffing levels, avoid cash-flow problems and prevent widespread bankruptcies in the wake of the lockdown.

The literature has struggled to fully comprehend how entrepreneurial activity is upended, mediated and realigned by crisis episodes, especially when they are global in nature (Doern et al., 2019; Herbane, 2010). Indeed, research on the impact of crisis events for entrepreneurs is sparse, and often narrow in focus. This is despite the fact that entrepreneurs and their businesses are often the most disadvantaged by crisis episodes (Ratten 2020). An important factor in understanding the impact that temporary, government restrictions have on small business and entrepreneurs is understanding the cost of a crisis and how it creates barriers and perceived obstacles for those who wish to continue (Hegarty et al., 2020). The financial strain, in many cases, leaves entrepreneurs with the issue of survival (Dimov, 2010; Simmons et al. 2014). This is both a formal barrier to continuation but also an informal barrier as it may result in risk aversion. Jenkins et al. (2014) caution that while business problems can provide valuable lessons this can come with a high emotional and financial cost, causing negative psychological effects for the entrepreneur. Furthermore, research suggests that entrepreneurs tend to exhibit high levels of psychological stress (Fowle 2019; Freeman et al. 2019). Significantly, according to Shepherd and Haynie (2011), the grief and negative emotions felt by entrepreneurs who experience failure can obstruct their future engagement with business and entrepreneurial activity.

In contrast, Hayward et al. (2010) and Corner et al. (2017) report that despite the trauma that comes with business problems, entrepreneurs often exhibit resilience. Resilience can be defined as the process of coping with stressors and change, enabling individuals to bounce back after experiencing a failure (Richardson 2002; Hayward et al. 2010; Bullough and Renko, 2013). Jenkins et al. (2014) suggest that entrepreneurs develop psychological capital after experiencing a crisis. Luthans and Youssef-Morgan, (2017) and Franco et al. (2020) present evidence that financial, operational and environmental factors have a significant influence over entrepreneurial resilience. In addition, entrepreneurs who display social resilience have a better ability to maintain and build upon relationships which might have been damaged due to a failed venture (Hayward et al. 2010). Resilience is important as it allows not only facilitates recovery but also learning.

There is an emergent, albeit small body of research on the short-term impacts that the restrictions imposed in response to COVID-19 have had on entrepreneurs. Our review of the literature indicates that entrepreneurs are vulnerable to periods of crisis because they lack key business resources (staff, finance, ICT based solutions etc.). There is evidence reported in the literature of the resilience of entrepreneurs and of the potential for valuable learning to emerge from crisis episodes. Our review of articles which deal specifically with entrepreneurs and the COVID-19 crisis (Bartik et al. 2020; Brown et al., 2020; Cowling et al., 2020; He and Harris, 2020; Kuckertz et al., 2020; Liguori and Pittz, 2020; Nummela et al., 2020; Papadopoulos et al., 2020; Ratten, 2020; Stephens et al., 2021a) indicates that studies on the impact of COVID-19 should examine four key themes: the psychological impact; the attitude of entrepreneurs; the changes that occur in their business activities; and the supports that are 
needed. Therefore, in our discussion section we present an overview of the key findings as they relate to the four themes identified in the literature.

\section{METHODOLOGY}

Authors including Low and McMillian (1998) and Breslin (2008) have proposed that the challenge for future entrepreneurship research is to continue to move towards explaining rather than documenting entrepreneurial phenomenon. However, we argue that the unique circumstances that have resulted from the COVID-19 crisis requires empirical work that is exploratory (Ratten, 2020) and that adopts a narrative based approach to reporting how COVID-19 has changed the lives of entrepreneurs (Nummela et al., 2020). The novelty of our study is based on the fact that we interviewed entrepreneurs five times over a period of six months. During this period the entrepreneurs faced a range of unique challenges. The imposition of business restrictions as a result of the COVID-19 pandemic saw all non-essential businesses close, then partially reopen, in many cases with significantly different business model and operating system. Given the motives for becoming an entrepreneur are often multi $\square$ faceted semi $\square$ structured interviews are an appropriate way of capturing the complexity of the process. The interview schedule was devised after a review of the literature and was sent to participants prior to the interviews. The interviews explored the entrepreneurs experience of the crisis, motivations for continuing, current activities and the types of supports that they need.

The methodology was designed to be responsive to the changing economic situation and the level of restrictions. The interviews were conducted at five stages. Each of the five stages correspond to a different level of economic and social activity being permitted. Therefore, there was some variation in the questions used in each interview.

\section{TIMELINE OF RESTRICTIONS/INTERVIEWS}

Stage 1: Week beginning March $16^{\text {th }}$. A nationwide lockdown was introduced. All non-essential businesses were closed. Movement was restricted to $5 \mathrm{~km}$. There was limited business activity due to restricted supply-chains and a lack of online capacity.

Stage 2: Week beginning May $5^{\text {th }}$. Some businesses had transitioned to an online model with social media-based marketing driving limited sales. The Government published its plan to reopen the economy on a phased basis.

Stage 3: Week beginning June $8^{\text {th }}$. Phase 2 of reopening had commenced. Non-essential retail was open for click and collect. Food and beverages were available for outside dining and indoor for hotel residents.

Stage 4: Week beginning July $7^{\text {th }}$. Phase 3 of Reopening (with some local lockdowns in place). Businesses that reopened did so with new: systems, on-site layouts and modified offerings. Businesses based on personal services i.e. hairdressers remained closed.

Stage 5: Week beginning August $25^{\text {th }}$. the majority of businesses had (re)opened but in a restricted capacity. Schools had also reopened. There was an expectation that society and the economy would operate in the "new normal" until such time as a vaccination programme was implemented.

Brush et al. (2009) argue that exploring the entrepreneurial narrative can make a unique contribution to our understanding of the phenomenon. Indeed, Smith (2009) explains that to be made meaningful for others, experiences, values, and achievements must be communicated to others via language, narrative and storytelling. Therefore, narrative structuring (Kvale 2006; Roundy 2016) was used to create a coherent story of the entrepreneurs' experiences. The interviews were conducted online via MS Teams or Zoom. The entrepreneurs were all based in Ireland. Each interview lasted on average 20 minutes. The total interview time was circa one hour and forty-five minutes for each entrepreneur. Although our study is novel in approach other studies have used multiple interviews over time to study micro firms and entrepreneurship (Crick, 2011; Jaskiewicz et al., 2015; Kelliher et al., 2020). The interviews were recorded, transcribed with note taking in line with recommendations from (Bryman, 2012; 
Saunders et al., 2015). The unit of analysis is an individual who had experienced a temporary business closure. Criterion sampling was applied. All the entrepreneurs: 1) had experienced business restrictions due to COVID-19; 2) had (re)started successfully; and 3) expected to continue in business during the remainder of 2020. Due to the sensitive nature of the topic and time constraints many potential participants declined to participate. A profile of the participants is provided in Table 1. Pseudonyms are used to ensure anonymity and to enhance the authenticity of the emergent narrative.

Table 1: Participants

\begin{tabular}{|c|c|c|c|c|c|c|c|}
\hline & Name & Gender & Age & Edu & Bus Age & Industry & Closure \\
\hline 1 & Aisling & Female & 40 & HE & 10 & Accommodation & 12 weeks \\
\hline 2 & Michael & Male & 55 & LC & 25 & Accommodation & 12 weeks \\
\hline 3 & Greg & Male & 40 & LC & 20 & Accommodation & 12 weeks \\
\hline 4 & Tom & Male & 55 & HE & 10 & Prof Services & 6 weeks \\
\hline 5 & Annette & Female & 40 & HE & 25 & Prof Services & $\mathrm{n} / \mathrm{a}$ \\
\hline 6 & Emma & Female & 35 & HE & 8 & Prof Services & $\mathrm{n} / \mathrm{a}$ \\
\hline 7 & Lorraine & Female & 35 & HE & 2 & Fitness/Health & 6 weeks \\
\hline 8 & Shaun & Male & 40 & LC & 1 & Fitness/Health & 16 weeks \\
\hline 9 & Rory & Male & 35 & HE & 2 & Fitness/Health & 16 weeks \\
\hline 10 & Claire & Female & 50 & LC & 15 & Retail & 12 weeks \\
\hline 11 & Liam & Male & 60 & LC & 30 & Retail & 12 weeks \\
\hline 12 & Linda & Female & 30 & LC & 10 & Retail & 6 weeks \\
\hline 13 & Abdul & Male & 45 & LC & 15 & Restaurant & 6 weeks \\
\hline 14 & Pat & Male & 50 & LC & 5 & Restaurant & 12 weeks \\
\hline 15 & Breda & Female & 30 & LC & 15 & Restaurant & 12 weeks \\
\hline
\end{tabular}

Eight of the entrepreneurs are male and seven are female. Their ages range from thirty up to sixty. The primary business of the entrepreneurs was in existence for between one and thirty years. Six of the entrepreneurs have completed higher education and the rest have completed second level (up to the leaving certificate or equivalent). The entrepreneurs can be classified by five business types with three from each industry. Two of the businesses did not close during the restrictions. One was deemed essential (cleaning) and the other is an online consultancy which required minimal operational adjustment. Four businesses were able to restructure and reopen after six weeks. Seven reopened after twelve weeks and two after sixteen weeks.

\section{FINDINGS}

The findings from the interviews are presented for each of the five stages:

\section{Stage 1: Interviews Week March $16^{\text {th }}$ Lockdown started}

We began by asking the entrepreneurs about their immediate reaction to the imposition of restrictions. As the following quotes suggest, many were in shock:

I just can't get my head around it. I was up town earlier and it is just surreal how everybody was saying goodbye to each other. (Greg)

It hasn't sunk in yet. I can't see how they can keep us closed, my members will be going up the walls. (Lorraine) 
These quotes provide insight into the broader societal reaction to the initial imposition of restrictions. During this initial interview there was no expectation of an extended period of closure. Indeed, there was no certainty regarding the duration of the pandemic. In response to the COVID-19 crisis, government and support agencies have focused on the short-term impacts on entrepreneurs (Brown et al., 2020). We then asked the entrepreneurs about what impact they expected the restrictions to have on them. For many it was an opportunity to pause, reflect and reassess:

I will just take time to take stock and maybe think about some jobs that need doing around the grounds and in the lobby. (Tom)

I am going to spend time with the family ... not sure how we are going to manage the kids with school. (Linda)

What will I do with myself? I am in here 60 hours a week. I will try and do my (fitness) classes online and see if that works for a few weeks. (Aisling)

It is interesting that the entrepreneurs acknowledged that they needed a "break" during which they planned to focus on other priorities and during which they could reassess their work/life balance. Next, we asked the entrepreneurs what resources and supports had they used and/or planned to use. Initially, and perhaps linked to the shock, the entrepreneurs turned to customers, other entrepreneurs and business managers in an attempt to gain a shared understanding:

Just talking with my clients and seeing what they think will happen. (Emma)

Chatting (online) with other owners and seeing what way they are handling things. (Breda)

This approach highlights the reliance of entrepreneurs on peers and informal business networks for both support and information. We then asked the entrepreneurs in what ways could the government support them. There was no clear idea other than a desire for information and an indicative timeline:

We need to know what is happening. (Greg)

When will we be back? (Rory)

The absence of a clear set of needs, indicates the uniqueness of situation. Interestingly, finance is not cited by the entrepreneurs but rather there is need for information that is clear and credible. The key observation from the first set of interviews is the initial shock that the entrepreneurs felt and their inability to comprehend the future. There was a sense of life almost standing still. However, many of the entrepreneurs used stage 1 as an opportunity to reflect on their business and adapt, while others used the time to engage in non-business-related activities.

\section{Stage 2: Interviews Week May $5^{\text {th }}(\mathbf{R e})$ opening Plan published}

At the start of the second set of interviews we asked the entrepreneurs how they and their business were impacted by the restrictions. At this point, many of the business remained closed and there was a sense of frustration:

It has been really strange. Going in to town is a hassle now and there is very little to do. (Claire)

I can't see how I am going to get going until after the summer ... then what is the bloody point. (Michael)

We have moved to a take-away system. It works okay ... but we can't move in that direction forever. (Pat)

Frustrations manifested themselves both in the restrictions on normal life and also on business activities. There was frustration at the closures and concern that the business may not survive. Even for those who were "open" there was concern about the long-term implications. For some of the entrepreneurs, the closure of their business reinforced how important the business was to them. For others, it offered them an opportunity to reflect on the impact (often negative) that being an entrepreneur has had on their family life and lifestyle. 
It shows how important the business is to me and how much I love being in the Hotel and seeing all the staff. (Aisling)

Maybe I was spending too much time in the restaurant. I have had a reality check on my lifestyle. (Breda)

We then asked the entrepreneurs what resources and supports had they used and/or planned to use. None were identified during stage 1. After six weeks the entrepreneurs had two main needs: the first, was support from their banks and second, technical help with online business operations.

I am hoping to talk to the bank next week and chatted with XXXX in the department (Social Welfare) about what the staff need to do. (Shaun)

We have had to be on to the bank nearly every day. But I really don't know where we stand. I am going to need to start again next year at this rate. (Annette)

I have needed a lot of technical support ... the wife better understands this stuff ... but I am starting to get a handle on Zoom now. (Tom)

We then asked the entrepreneurs about how their community, government or other organisations could provide support to them. The main priority was finance, either in the form of an exemption or grant aid:

We need help with the cost of reopening, the cleaning and staff training will cripple us. (Michael)

I need my rates forgotten about for the next few years. (Pat)

I need my landlord to drop my rent. (Rory)

The need for subsidies and grants captures the vulnerability of the businesses. Many already operating on tight margins could not absorb the additional operating costs. Managing staffing levels and costs are a key element of creating a sustainable margin for a small business. Many operate in a competitive market, which in normal times has low barriers to entry. The entrepreneurs were next asked what advice they would give to others who have seen their business close. Some of the practical ideas, relating to improving business operations, included:

Talk to the bank and figure out the bills and wages (Pat).

Chat to $X X X X$ at $X X$ Cleaning Services there is so much to be done before you reopen. (Linda)

Get your accountant to sort out access to every grant going. Tell the bank to give you space until 2021. (Michael)

Tighten up on your costs, mainly staff and think about having an online version for most of your customers. (Emma)

Get organized online, build up Instagram it will generate a lot of opportunities. (Lorraine)

It could be argued that these ideas are not unique to a crisis situation, for instance the development of online activities should have already been underway. During this stage, it was obvious the entrepreneurs were experiencing stress and frustration. This was as a result of the unknown and the financial implications of being closed. At this point, receiving support from financial institutions and government bodies was imperative for the entrepreneurs to ensure they could (re)open.

\section{Stage 3: Interviews Week June $8^{\text {th }}$ Phase 2 of $(\mathrm{Re})$ opening}

At the start of this round of interviews we asked the entrepreneurs about their experiences of (re)opening and/or preparing to reopen. The following quotes highlight the challenges the entrepreneurs experienced: 
It is a nightmare. We have so much cleaning to do. It's extra staff and then more [staff] for the queuing system. We can't do this for too long because we don't have any margin. (Breda)

It just isn't the same. I didn't get into this to be take-away. I want to be full on the weekends but that is never going to happen. (Pat)

I am still waiting. I see others doing stuff (exercise classes) outside! That is not fair and anyway it's no use without the big equipment. (Rory)

Having struggled while their business was closed, the entrepreneurs continued to face difficulties as they reopened. Different products and services were better suited to the limitations of reopening. This created a sense of inequality and frustration. This frustration was amplified by the entrepreneurs benchmarking their activities against those of pre-COVID times. Acceptance of an emerging "new normal" was absent during stage 3. The entrepreneurs sought support in two ways. First, from other business owners and second from engagement with their financial institution.

I am contacting other businesses and checking what they are doing. XXXX has a really good set-up but they have a car park. Being a restaurant on the main street is very tricky now. (Pat)

We have everything paused with the banks. But in September we will need to talk to them again because we don't have the same income any more. (Greg)

Next, we asked the entrepreneurs how they felt the government/community/others could provide support to them. The responses highlight two key needs. First, the entrepreneurs needed help with additional operational costs and second, they required assistance with promotions and incentives to nudge customers back into their old habits and routines:

We are spending way more on housekeeping. If I push up the room rates I will have no guests. We need tax relief on cleaning products and money to buy purifiers. (Michael)

I need ... like ... a spray gun for disinfecting the machines and bikes after each client/class. The quotes are crazy so we need to be able to get it for cheap. (Shaun)

I need promotion and marketing to show people that we are open. The chamber (of Commerce) should be giving us help to run a campaign to get people on to the main street. (Breda)

We need Board Failte to push for staycations and get as many people into this county as possible. I am way behind and need to be fully booked this month. (Aisling)

The key issue highlighted during this stage is how quickly consumer habits can change and that consumers did not on mass return to previous consumption patterns when the opportunity arose. Next, we asked the entrepreneurs to provide advice to others who were (re)opening their business. Interestingly, the entrepreneurs focused on operations, cost savings and resource management:

Manage your staff. Get them working at home where they are happy. Think about your office space and how to reduce it. It takes too much to manage it now. (Annette)

I have moved away from the restaurant to take-away only. I will save on rent and money I didn't have the time or energy to be working at cleaning and stupid seating arrangements that don't pay staff. (Abdul)

The experience of (re)opening brought additional stress and costs for the entrepreneurs. They also had to deal with a consumer base that had different levels of adherence to the guidelines and different levels of concerns about the virus. They sought support from fellow entrepreneurs, engaging with them to gain an understanding of how they were adapting their business models. The additional cost of staffing their business along with the 
stringent processes required to adapt the business to comply with the COVID-19 restrictions were areas in which the entrepreneurs felt they needed support.

\section{Stage 4: Interviews Week July $7^{\text {th }}$ Phase 3 of $(\mathrm{Re})$ opening}

At start of the interviews we asked the entrepreneurs about their experiences of (re)opening. Two of the entrepreneurs had not (re)opened because they had taken up employment in retail and needed additional time to redesign their work schedules. This may be indicative of a pattern of entrepreneurial exit that merits further study. With exit during this period needs to be studied at both an individual and firm level (Parastuty, 2018). At this stage the entrepreneurs reported a greater sense of positivity as they had (re)opened and were starting to gain momentum.

We are back. There is traffic on the main street and the shops and cafes are really pushing hard to get people in and looked after. (Pat)

We are so busy. Everyone just wants to be back to normal. Even with less seats we are doing a lot of covers and the outside (area) seems to work well. (Breda)

Even with our leisure center closed the bookings are great. Our turnover in the bar is up. We have created family (eating) spaces in the ballroom. (Michael)

The sense of inequality and negativity that was evident in stage 3 was replaced with a renewed motivation to (re)create a business, where previously there were limitations, there was now a sense of opportunity, linked the reemergence of business activity. When asked how the government, community or others could provide support at this stage, the entrepreneurs all focused on keeping the economy open. Many were happy to be open and felt that they had adapted their operations to fit with the new normal.

We are so busy. I need people to be able to come to the county and then we can look after them. (Greg)

We are back out helping our clients. They are happy to be open and I am really glad we are helping them and their staff. (Annette)

So many new customers and all of them online which is great for me and for them. None of us miss the driving. (Emma)

Entrepreneurs constantly work to adapt and modify their offerings and there is evidence that during stage 4 this was the focus (once a credible future pattern of activity was established). Finally, we asked the entrepreneurs what advice would they give to others who were (re)opening their business.

Spend lots of time with your staff. Once they are happy and feel safe everything else will sort itself out. (Pat)

Keep checking in on your customers and don't just ring them to sell something, start by offering them help. (Tom)

Get your clients to commit to a six-week plan. Get them back in a routine and money coming in. (Shaun)

The entrepreneurs were motivated and positive at this stage. They had accepted the new business environment; taken inspiration from other business owners; responded to new customer needs; and the new needs of their existing customers. The support they most needed was keeping the economy open at this point. Having adapted their businesses, most were happy with how the business was performing, they were busy and enjoying being open again.

\section{Stage 5: Interviews Week Aug 25 $5^{\text {th }}$ New Normal in Operation (Schools (re)open)}

The final set of interviews took place in late August. At this time all the businesses had reopened, albeit under very different circumstances. At the start of the interviews we asked the entrepreneurs to reflect on their experiences over the previous six months. The majority of the entrepreneurs saw a positive future, even those who were less 
optimistic about the economic outlook were committed to continuing their entrepreneurial journey.

If we can stay open then I think our trade will be okay. The bar is doing well and we have better staffing levels. We really need to get back to weddings. (Greg)

I am very busy and have found ways of working with customers to keep things busy. (Lorraine)

The gym is taking off. People just want somewhere to go and we have a cool community here. (Shaun)

I am not sure what will happen but as long as our take-away isn't closed then we will keep going. (Pat)

We asked the entrepreneurs about the key business and/or life lessons that they had learnt. Many had taken time to evaluate their business, to gain new ideas and to focus on what really works in their business. From a negative came a positive. Many of the entrepreneurs had new, leaner business models which were better aligned with evolving consumer needs. Where appropriate online sales and service provision had been developed resulting in new customers.

Take a step back. I was in the hotel night, noon and day. Time at home gives you new ideas. (Michael)

Cut costs. You can save so much on staff. I have a really good team in my XXXX location. Now I just need to get the right guys in my main place. (Pat)

I was trying way too many things, now I just focus on winners. Simple ideas that don't cost money and bring in customers. (Aisling)

Just having a clinic (building), you can miss out on so many clients. The amount (of clients) I have now for online consultations is brilliant. (Lorraine)

Finally, we asked the entrepreneurs about their expectations for their business and their local business community in 2021. There was significant concern about another lockdown but optimism for 2021.

It will be really hard if there is another lockdown. If we can keep going until Halloween then we might just close up anyway until St Patrick's (March 17th) and then get going again. (Aisling)

I can do a little bit online but realistically I need to be allowed stay open so that I can run classes and do my PT stuff. (Rory)

My business is much better now. I can do a lot more things even in a lockdown. Next year I will really push on. I have great plans. (Emma)

The main street is already in trouble so we need to get that sorted next year. We are all just muddling through until this is over. (Pat)

The entrepreneurs were accepting of the situation at this stage. They desired for a period of certainty, but accepted that this would not occur until mass vaccination was implemented. In the short-term (winter 2020-21) they hoped that as much of the economy as possible would remain open. As the level of change in relation to business activity normalized they were thinking more long term.

\section{DISCUSSION}

Table 2 presents an overview of the key findings as they relate to the four themes identified in our literature review. 
Table 2: Matrix of findings for each stage and each theme from the literature

\begin{tabular}{|c|c|c|c|c|c|}
\hline Theme & $\begin{array}{c}\text { Stage } 1 \\
\text { March 16th }\end{array}$ & $\begin{array}{l}\text { Stage } 2 \\
\text { May } 5 \text { th }\end{array}$ & $\begin{array}{l}\text { Stage } 3 \\
\text { June 8th }\end{array}$ & $\begin{array}{l}\text { Stage } 4 \\
\text { July } 7 \text { th }\end{array}$ & $\begin{array}{l}\text { Stage } 5 \\
\text { Aug 25th }\end{array}$ \\
\hline Psychological & $\begin{array}{l}\text { Life stands still, unable } \\
\text { to comprehend. }\end{array}$ & $\begin{array}{l}\text { Post-shock reflection } \\
\text { on work/life balance. }\end{array}$ & $\begin{array}{l}\text { Despair and } \\
\text { frustration. }\end{array}$ & $\begin{array}{l}\text { Relief and joy at } \\
\text { reopening. }\end{array}$ & $\begin{array}{l}\text { Acceptance of the } \\
\text { situation and hopeful. }\end{array}$ \\
\hline Attitudes & $\begin{array}{l}\text { Focus on others, } \\
\text { particularly family } \\
\text { members. }\end{array}$ & $\begin{array}{l}\text { Realise that their } \\
\text { business is a key part } \\
\text { of their identity. }\end{array}$ & $\begin{array}{l}\text { Difficult to see } \\
\text { positives, problem } \\
\text { focused. }\end{array}$ & $\begin{array}{l}\text { Pushing to maximise } \\
\text { turnover and catch-up. }\end{array}$ & $\begin{array}{c}\text { Benefitted from a } \\
\text { period of reflection. }\end{array}$ \\
\hline Business & $\begin{array}{l}\text { Taking time to } \\
\text { consider how best to } \\
\text { improve. }\end{array}$ & $\begin{array}{l}\text { Limited activity. } \\
\text { Exploring online } \\
\text { options. }\end{array}$ & $\begin{array}{l}\text { Risings costs and } \\
\text { reduced turnover. }\end{array}$ & $\begin{array}{l}\text { Busy due to residual } \\
\text { demand/finance. }\end{array}$ & $\begin{array}{l}\text { Made improvements } \\
\text { and diversified. }\end{array}$ \\
\hline Supports & $\begin{array}{l}\text { Searching for accurate } \\
\text { information. }\end{array}$ & $\begin{array}{l}\text { Need credit } \\
\text { extensions. }\end{array}$ & $\begin{array}{l}\text { Networking with other } \\
\text { entrepreneurs. }\end{array}$ & $\begin{array}{l}\text { Need Information } \\
\text { to help make future } \\
\text { plans. }\end{array}$ & $\begin{array}{l}\text { Dependent on the } \\
\text { duration of the crisis. }\end{array}$ \\
\hline
\end{tabular}

Table 2 provides an indication that for the entrepreneurs the appraisal of the situation was an iterative process. The evidence presented in Table 2 shows that the impacts of the restrictions can be tracked over time (the 5 stages). The impacts are varied and subject to change over time. We believe that the four themes identified in the literature are a useful lens with which to frame and organise our findings.

Table 2 illustrates that the imposition of restrictions and temporary closures impact an entrepreneur in four ways. First, the entrepreneurs experienced a significant level of psychological stress but over time they accepted the changed circumstances and focused on continuation. This supports evidence in the literature on the resilience of entrepreneurs, especially during crisis episodes (Spillan and Hough, 2003; Shepherd and Haynie, 2011; Jenkins et al., 2014; Hegarty et al., 2020; Stephens et al., 2021a). Second, initially the entrepreneurs focused on their family, staff and customers. But over time they engaged in reflection with a focus on work/life balance and/or the type of product/service that they want to provide. This is a novel insight and points to a need to explore the impact of "breaks", both voluntary and imposed that occur during an entrepreneurial journey. Third, in response to the crisis the entrepreneurs were willing to consider any option that allowed them to continue in business. However, over time their focus was on the retention and development of their core business, to which they have an emotional attachment to (Singh, 2015; Williams and Shepherd, 2016; Hegarty et al. 2020). Our findings indicate that during the COVID-19 there were some novel reactions, caused by different business being impacted for different periods of time and in different ways depending on the core product or service. Fourth, and finally, the entrepreneurs needed different types of supports at different stages of the crisis, from closure through to re-opening. Initially, it was accurate and up-to-date information. Then practical supports to help maintain liquidity and then accurate information to allow them to engage in meaningful planning. In the medium-term entrepreneurs who have been impacted by COVID-19 will need supports for their business, and importantly for themselves. The entrepreneurs need access to their peers and business community. This is for social support, to share experiences (to alleviate the psychological impacts) and to allows them to understand how best to support their employees.

Additional staffing needs, less capacity for customers and strict cleaning procedures requiring specialist equipment were some of the financial challenges incurred by the entrepreneurs upon (re)opening. For the entrepreneurs who were able to develop online provision, this resulted in new business opportunities and revenue streams (Di Domenico et al., 2014; Daniel et al., 2015). However, the entrepreneurs experienced distress as a result of the impact that the uncertainty had on their families, their staff and their peers in their business community. (Politis and Gabrielsson, 2009; Jenkins et al., 2014; Simmons et al., 2014; Shepherd, et al., 2016; Hegarty et al., 2020).

The evidence from our interviews indicates that a temporary business closure has a significant impact on the psychological wellbeing of an entrepreneur. During this study the entrepreneurs had to deal with a great deal of stress and uncertainty. However, the entrepreneurs responded by engaging in a period of reflection resulting in new business ideas and different perspectives on their work/life balance. The need for achievement is an important trait in motivating entrepreneurs and irrespective of external shocks and the associated uncertainty entrepreneurs will still retain a desire to (re)achieve. For the entrepreneurs the decision to continue their entrepreneurial journey is framed by resilience linked to work satisfaction, loyalty to staff and customers; and a shared identity with their business community and peers. In this unique scenario dealing with the unknown was the biggest challenge. Despite the 
best efforts of government and health agencies the COVID-19 restrictions continue. Appropriate support systems are complex to design and deliver. The situation is fluid and so financing interventions is a significant challenge and appropriate support systems are complex to design and deliver (Brown et al., 2020; Liguori and Pittz, 2020; Papadopoulos et al., 2020; Stephens et al., 2021b).

\section{CONCLUSION}

A business closure can devastate an entrepreneur leaving them in shock and left to deal with the emotional and financial impacts (Corner et al., 2017). However, the entrepreneurs in this study used their time to evaluate and reassess their business, looking at how they could adapt and improve their processes, offerings and resource allocation. The entrepreneurs displayed resilience as they adapted rapidly and changed their business model to fit with the limitations of the business environment. Additional financial strain occurred as a result of the rigorous processes and procedures imposed on the businesses. The findings highlight the importance of providing entrepreneurs with timely information, guidance and the opportunity to share their experiences with others in the same situation. Some of the entrepreneurs felt more supported than others, some were better able to adapt. Therefore, entrepreneurs should not be thought of as a homogeneous group during crisis episodes. The evidence from our study provides a snapshot of the perceptions of entrepreneurs who faced temporary business closure due to the COVID-19 pandemic. Furthermore, the findings offer insights for policy makers who wish to aid business recovery. The length of the pandemic will inevitable determine the scale and scope of government interventions. Entrepreneurs who have been impacted by COVID-19 need supports for their business, and for themselves. We conclude by acknowledging the limitations of our study. The data collection process was subject to significant time constraints. The data was collected during a period of great change for the entrepreneurs. Their availability to participate in our study was extremely limited. Our sample size is small and a greater number of respondents and from different jurisdictions would add additional perspective. Although the transcripts are detailed and represent a biographical account a longitudinal study may provide greater insights. Additional research is needed into the longterm impacts of the business restrictions, specifically, the rates of entrepreneurial exit and the use of qualitative methods to explore the reasons and outcomes.

\section{ACKNOWLEDGMENT}

The authors wish to acknowledge the invaluable contribution of the editors and the reviewers. Their guidance and recommendations have resulted in significant improvements to this paper.

Simon Stephens is a Senior Lecturer in Small Business Economics at Letterkenny Institute of Technology. His current research explores the impact of the COVID-19 crisis on the small business community. His recent publications can be found in the Journal of Business Venturing Insights and the International Journal of Gender and Entrepreneurship.

Dr Christopher McLaughlin is a Teaching Fellow in Business Analytics at the University of Ulster. He is the course director for the BSc in Business Analytics. His recent publications can be found in Supportive Care in Cancer, The British Food Journal and the Journal of Retailing and Consumer Services.

Dr Katrina McLaughlin is a Lecturer in Psychology at Queens University Belfast. Her research interests centre around parent child interactions and the evaluation of psychosocial interventions. Her recent publications can be found in the Journal of Community \& Applied Social Psychology and the Journal of Child Psychology and Psychiatry 


\section{References}

Alonso, A.D., Kok, S., Bressan, A., O'Shea, M., Sakellarios, N., Koresis, A., Solis, M. and Santoni, L. (2020). 'COVID-19, aftermath, impacts, and hospitality firms: An international perspective'. International Journal of Hospitality Management, 91, 102654.

Bartik, A.W., Bertrand, M. and Cullen, Z. (2020). 'The impact of COVID-19 on small business outcomes and expectations'. Proceedings of the National Academy of Sciences, 117(30), 17656-17666.

Breslin, D. (2008). 'A review of the evolutionary approach to the study of entrepreneurship'. International Journal of Management Reviews, 10, 399-423.

Brown, R., Rocha, A. and Cowling, M. (2020). 'Financing entrepreneurship in times of crisis: Exploring the impact of COVID-19 on the market for entrepreneurial finance in the United Kingdom'. International Small Business Journal Researching Entrepreneurship, 38(5), 380-390.

Bryman, A. (2012). Social Research Methods, Oxford University Press, Oxford.

Brush, C., de Bruin, A. and Welter, F. (2009). 'A gender-aware framework for women's entrepreneurship'. International Journal of Gender and Entrepreneurship, 1(1), 8-24.

Bullough, A. and Renko, A. (2013). 'Entrepreneurial resilience during challenging times'. Business Horizons, 56(3), 343-350.

Corner, P. D., Singh, S. and Pavlovich, K. (2017). 'Entrepreneurial resilience and venture failure'. International Small Business Journal, 35(6), 687708.

Cowling, M., Brown, R. and Rocha, A. (2020). 'Did you save some cash for a rainy COVID-19 day? The crisis and SMEs', International Small Business Journal, 38(7), 593-604.

Crick, D. (2011). 'Enterprising individuals and entrepreneurial learning: A longitudinal case history in the UK tourism sector'. International Journal of Entrepreneurial Behavior \& Research, 17(2), 203218.

Daniel, E.M., Domenico M.D. and Sharma S. (2015). 'Effectuation and home-based online business entrepreneurs'. International Small Business Journal; 33(8), 799-823.

Di Domenico, M., Daniel, E. and Nunan, D. (2014). 'Mental mobility in the digital age'. New Technology, Work and Employment, 29(1), 266-281.

Dimov, D. (2010). 'Nascent Entrepreneurs and Venture Emergence: Opportunity Confidence, Human
Capital, and Early Planning: Nascent Entrepreneurs and Venture Emergence'. Journal of Management Studies, 47(6), 1123-1153.

Doern, R., Williams. N. and Vorley, T. (2019). 'Special issue on entrepreneurship and crises: Business as usual? An introduction and review of the literature'. Entrepreneurship \& Regional Development, 31(56), 400-412.

Foss, N.J. (2020). 'Behavioral strategy and the COVID-19 disruption'. Journal of Management, 48(6), 1322-1329.

Fowle, M. (2019). 'The entrepreneurial dream: Happiness, depression and freedom'. International Review of Entrepreneurship, 17(3), 305-322.

Freeman, M.A., Staudenmaier, P.J., Zisser, M.R. and Andresen, L.A. (2019). 'The prevalence and co-occurrence of psychiatric conditions among entrepreneurs and their families'. Small Business Economics, 53(2), 323-342.

Franco, M., Haase, H. and António, D. (2020). 'Influence of failure factors on entrepreneurial resilience in Angolan micro, small and medium-sized enterprises', International Journal of Organizational Analysis, 29(1), 240-259.

Giones, F., Brem, A., Pollack, J., Michaelis, T., Klyver, K. and Brinckmann, H. (2020). 'Revising entrepreneurial action in response to exogenous shocks: Considering the COVID-19 pandemic', Journal of Business Venturing Insights, 14, e00186.

Hayward, M.L.A., Forster, W.R., Sarasvathy, S.D. and Fredrickson, B.L. (2010). 'Beyond hubris: How highly confident entrepreneurs rebound to venture again'. Journal of Business Venturing, 25(6), 569578.

He, H. and Harris, L. (2020). 'The Impact of Covid-19 Pandemic on Corporate Social Responsibility and Marketing Philosophy'. Journal of Business Research, 116(1), 176-182.

Hegarty, C., Stephens, S., Gallagher, P. and Cunningham, I. (2020). 'Entrepreneurs and Business failure: taking a second chance', International Review of Entrepreneurship, 18(4), 521-540.

Herbane, B. (2010). 'Small business research: Time for a crisis-based view'. International Small Business Journal 28(1): 43-64.

Jaskiewicz, P. Combs, J.G. and Rau, S. (2015). Entrepreneurial legacy: Toward a theory of how some family firms nurture transgenerational entrepreneurship. Journal of Business Venturing, 30(1), 29-49. 
Jenkins, A.S., Wiklund, J. and Brundin, E. (2014). 'Individual responses to firm failure: Appraisals, grief, and the influence of prior failure experience'. Journal of Business Venturing, 29(1), 17-33.

Kelliher, F., Mellett, S. and Harrington, D. (2020). 'Enablers of green innovation in the micro-firm perspectives from Ireland and Canada'. Journal of Small Business \& Entrepreneurship, https://doi.org /10.1080/08276331.2020.1789826

Kvale, S. (2006). Interviews: an introduction to qualitative research interviewing, Sage Publications, London and Thousand Oaks, California.

Kuckertz A., Brändle L. and Gaudig A. (2020). 'Startups in times of crisis -A rapid response to the COVID-19 pandemic'. Journal of Business Venturing Insights, 13: e00169.

Liguori, E.W. and Pittz, T.G. (2020). 'Strategies for small business: Surviving and thriving in the era of COVID-19', Journal of the International Council for Small Business, 1(2), 106-110.

Liguori, E. and Winkler, C. (2020). 'From offline to online: challenges and opportunities for entrepreneurship education following the COVID-19 pandemic'. Entrepreneurship Education and Pedagogy, 3(4), 346-351.

Low, M.B. and MacMillan, I.C. (1998). 'Entrepreneurship: Past Research and Future Challenges', Journal of Management, 14(2), 139-161.

Luthans, F. and Youssef-Morgan, C.M. (2017). 'Psychological Capital:An Evidence-Based Positive Approach'. Annual Review of Organizational Psychology and Organizational Behavior, 4(1), 339-366.

Nummela, N., Paavilainen-Mäntymäki, E., HarikkalaLaihinen, R. and Raitis J. (2020). 'When all doors close: Implications of COVID-19 for cosmopolitan entrepreneurs', International Small Business Journal, 38(8), 711-717.

Papadopoulos, T. Baltas, K. and Balta, M.A. (2020). 'The use of digital technologies by small and medium enterprises during COVID-19: Implications for theory and practice', International Journal of Information Management, Vol. 55, 102192.

Papaoikonomou, E., Segarra, P. and Li, X. (2012). 'Entrepreneurship in the Context of Crisis: Identifying Barriers and Proposing Strategies'. International Advances in Economic Research 18(1), 111-119.

Parastuty, Z. (2018). 'Systematic review of research on exit: A bibliometric analysis and future directions'. International Review of Entrepreneurship, 16(4), 587-626.

Politis, D. and Gabrielsson, J. (2009). 'Entrepreneurs' attitudes towards failure: An experiential learning approach'. International Journal of Entrepreneurial Behavior and Research, 15(4), 364-383.

Ratten, V. (2020). 'Coronavirus (Covid-19) and entrepreneurship: cultural, lifestyle and societal changes'. Journal of Entrepreneurship in Emerging Economies, 13(4), 747-761.

Richardson, G.E. (2002). 'The metatheory of resilience and resiliency', Journal of Clinical Psychology, 58(3), 307-321.

Roundy, P.T. (2016). 'Start-up Community Narratives: The Discursive Construction of Entrepreneurial Ecosystems'. Journal of Entrepreneurship, 25(2), 232-248.

Saunders, M.N.K., Lewis, P. and Thornhill, A. (2015). Research Methods for Business Students, 7th ed, Pearson Education, New York.

Shepherd, D.A. and Haynie, J.M. (2011). 'Venture failure, stigma, and impression management: $A$ self-verification, self-determination view', Strategic Entrepreneurship Journal, 5(2), 178-197.

Shepherd, D.A., Patzelt, H., Williams, T.A. and Warnecke, D. (2016). 'How Does Project Termination Impact Project Team Members? Rapid Termination, Creeping Death, and Learning from Failure: Creeping Death and Learning from Failure'. Journal of Management Studies, 51(4), 513-546.

Singh, S., Corner, P.D. and Pavlovich, K. (2015), 'Failed, not finished: A narrative approach to understanding venture failure stigmatization', Journal of Business Venturing, 30(1), 150-166.

Simmons, S.A., Wiklund, J. and Levie, J. (2014). 'Stigma and business failure: implications for entrepreneurs' career choices'. Small Business Economics, 42(3), 485-505.

Smith, R. (2009). 'Mentoring and perpetuating the entrepreneurial spirit within family business by telling contingent stories'. New England Journal of Entrepreneurship, 12(2), 27-40.

Spillan, J. and Hough, M. (2003). 'Crisis planning in small businesses: Importance, impetus and indifference', European Management Journal, Vol. 21 No. 2, pp. 398-407.

Stephens, S., Cunningham, I. and Kabir, Y. (2021a). 'Female entrepreneurs in a time of crisis: evidence from Ireland', Gender and Entrepreneurship, 13(2), 106-120.

Stephens, S., McLaughlin, C. and McLaughlin, K. (2021b) 'Small business in a time of crisis: a fivestage model of business grief', Journal of Business Venturing Insights, https://doi.org/10.1016/j. jbvi.2021.e00282 
Williams, T.A., and Shepherd, D.A. (2016). 'Victim entrepreneurs doing well by doing good: Venture creation and well-being in the aftermath of a resource shock', Journal of Business Venturing, 31(4), 365-387.
Zighan, S., Abualqumboz, M., Dwaikat, N. and Alkalha, Z. (2021). 'The role of entrepreneurial orientation in developing SMEs resilience capabilities throughout COVID-19'. The International Journal of Entrepreneurship and Innovation. https://doi. org/10.1177/14657503211046849 